\title{
OPTIMAL MOMENT TO CHANGE PRESSURE REGULATOR AND SPRAYER KIT ON CENTER PIVOT IRRIGATION MACHINES: APPLICATION TO A STUDY CASE
}

\author{
Ramón Pérez Leira ${ }^{1}$, Rodrigo Máximo Sánchez-Román*², José Antonio Frizzone ${ }^{3}$ \\ ${ }^{1}$ CNPq fellow. Associate professor at Hydraulic Investigations Center. Instituto Superior Politécnico "José Antonio \\ Echeverría" (ISPJAE). E-mail: rpleira@,cih.cujae.edu.cu \\ ${ }^{2}$ Professor at São Paulo State University, Agricultural Science College (UNESP-FCA), Botucatu, São Paulo (SP), \\ Brazil, e-mail: rmsroman@fca.unesp.br \\ ${ }^{3}$ Full Professor at Escola Superior de Agricultura "Luiz of Queiroz", University of São Paulo ( ESALQ-USP). E- \\ mail: frizzone@esalq.usp.br
}

\section{ABSTRACT}

A theoretical model developed by the authors for determining the optimal moment to substitute sprayer and pressure regulator kit on a center pivot irrigating potatoes and beans has been applied. The methodology compares the sum of the costs due to additional consumption of water and energy, maintenance and labor, as well as yield losses associated to areas with deficit or over irrigation to the costs due to buy and install a new sprinkling set on the pivot. The results showed that for a reduction of $3.07 \%$ of the Hermann and Hein's Uniformity Coefficient (UCh), the substitution of the sprinkling module on the pivot is justified when potatoes and beans are cultivated.

Keywords: pivot irrigation, emitters, uniformity, costs, potato, bean

\section{INTRODUCTION}

During the last four decades, several studies have been carried out to analyze the substitution of different irrigation methods for center pivot irrigation machines (CPIM) (Wood et al. 2007). The improvement of center pivot in terms of efficiency and sustainability under diverse climate, soil and crop conditions has also been studied. Although, most of these studies are focused on improving management and the use of different sprinkler devices; it is not common to find references regarding maintenance and lifetime cycle of emission devices.

Perez et al. (2011) carry out a theoretical approach to determine the optimal time for changing the sprinkling module on a CPIM, based on economical criteria. Using that methodology, a practical application for irrigated potato and bean crops was performed for Brazilian agricultural condition.

\section{MATERIAL AND METHODS}

In the State of São Paulo, Brazil, CPIM have usually a length of $504.75 \mathrm{~m}$. A CPIM was designed to satisfy the irrigation requirements for potato and bean crops. Fixed and variable costs for irrigation using a CPIM with a brand new sprinkling module were determined. 
Simulations increasing operation time were performed and costs were estimated considering less uniform irrigation due to worn emitters.

Main characteristics of the irrigation system:

\section{Center Pivot Irrigation Machine Characteristics:}

Length: $504.75 \mathrm{~m} \quad$ Inlet Flow Rate: $99.71 \mathrm{~L} \mathrm{~s}^{-1}$

Irrigation Area: 80 ha Inlet Pressure: $49.95 \mathrm{~m}$

Flow: $1.25 \mathrm{~L} \mathrm{~s}^{-1} \mathrm{ha}^{-1} \quad$ Pressure in the Tip: $21 \mathrm{~m}$

\section{Pump}

Engine: Electric

Total Dynamic Head: 64.95 m

Suction Head: $1,5 \mathrm{~m}$
Pivot Height: $4 \mathrm{~m}$

Type of Emitter: Spray

Engine Power: $101.69 \mathrm{~kW}$

\section{Crops' Data}

Potatoes (Solanum tuberosum) and beans (Faseolus vulgaris) were considered as sample crops to perform a study case. Detailed data about parameters related to irrigation schedule are found in the Table 1.

Table 1. Irrigation schedule for potatoes and beans at São Paulo State, Brazil

\begin{tabular}{ccc}
\hline Item & Potato & Bean \\
\hline Planting Date & May 1st & September 10th \\
Crop Cycle (days) & 110 & 113 \\
Water Consumption for Potential Yield \\
$\begin{array}{c}(\mathrm{mm}) \\
\text { Effective Rainfall during growing season } \\
(\mathrm{mm})\end{array}$ & 626.20 & 572.57 \\
$\begin{array}{c}\text { Total Gross Irrigation Depth (mm) } \\
\text { (for an irrrigation efficiency of } 85 \%) \\
\text { Irrigations Events }\end{array}$ & 026.20 & 200.4 \\
$\begin{array}{c}\text { Potencial Yield }\left(\mathrm{kg} \mathrm{ha}^{-1}\right) \\
\quad 26\end{array}$ & 372.2 \\
\hline
\end{tabular}
(2011):

To determine each of the terms in the general inequality (1) proposed by Perez et al.

$P M R+C I M \geq A E C C+A W C C+A L C+A M C+Y L C$

where PMR is the price of pressure regulator and nozzle kit; CIM is the installation cost of the kit on the CPIM; AECC is the additional energy consumption cost; AWCC is the additional water consumption cost; ALC is the additional labor consumption cost; AMC is the additional maintenance cost; and YLC is the yield losses cost.

Fixed Costs (PMR+CIM) Calculation. The installation lost of each sprayer set and its pressure regulator, including material and labor, is equal to US\$ 43.33. The total substitution cost for all emitter points along the pivot is equal to the number of emitter points on the CPIM times the unit 
cost. To know how many emitters are on the pivot, the total pivot length was divided by the emitter spacing.

Additional Energy Consumption Cost Computation (AECC). Additional energy consumption cost (AECC) was determined knowing irrigation schedule required to irrigate potato and bean fields with a new set and with an old one, generating a minor $\mathrm{UC}_{\mathrm{h}}$ each time. The increase in irrigation depth to compensate the decrease in $\mathrm{UC}_{\mathrm{h}}$ was determined by the relation proposed by Peri et al. (1979), $i=\frac{\beta}{\varepsilon}$; where $\beta$ is the gross income reduction times the water deficit volume unit; $\alpha$ is the gross income reduction times the water excess volume unit; and $i$ is the irrigation depth increase.

The increase in irrigation time (ITr) was defined considering that total irrigation time was a known value for potatoes and beans, when new and old emitter sets were used. Eq. 2 determines the differences in power consumption associated to irrigation time increase to compensate lack of uniformity when using the old emitter set.

$A E C C=\left(F D a_{T C}+F C a_{T C}\right) \frac{0.92}{\operatorname{cose}}(1+I C M S)(I T r-1)$

where $\mathrm{FDa}_{\mathrm{TC}}$ is the annual power demand bill for conventional rate (US\$); $\mathrm{FCa}_{\mathrm{TC}}$ is the annual power consumption bill for conventional rate (US\$); $\cos \varphi$ is the power factor; ICMS is the tax on circulation of goods and services in the region (decimal); and ITr is the irrigation time increase (decimal).

Power consumption rates from Compañía Paulista de Força e Luz (2007) are presented in Table 2. All values were converted to US\$ considering 1.8 brazilian real per US dollar, using the exchange rate set by the Brazilian Central Bank (2007).

Table 2. Power rates for consumer Group A4 used to analyze power consumption

\begin{tabular}{ccc}
\hline Rate & Factors $\left(\mathrm{US \$} \mathrm{kW} \mathrm{k}^{-1}\right)$ & Price \\
\hline \multirow{2}{*}{ Conventional Rate } & Demand & 18.74 \\
& Consumption & 0.1497 \\
\hline
\end{tabular}

Additional Water Consumption Cost (AWCC). To compute AWCC Eq. 3 was used.

$A W C C=Q \cdot \Sigma_{1}^{12} H(I T r-1) \cdot P a$

where $\mathrm{Q}$ is the CPIM flow rate $\left(\mathrm{m}^{3} \mathrm{hr}^{-1}\right)$; $\mathrm{Pa}$ is the water price, valued in $0.02 \mathrm{US} \$ \mathrm{~m}^{-3}$; and $\mathrm{H}$ is the monthly irrigation time $(\mathrm{h})$.

Labor Consumption Additional Cost (ALC). To compute ALC Eq. 4 was used

$A L C=\sum_{\text {irrigation }}^{n}=1\left[\frac{s}{240}\right] \cdot\left[1+\left(\frac{\text { Holidays }+\pi 13+7 W S S+2 T}{100}\right) \cdot \operatorname{Hr} \cdot(U T r-1)\right]$

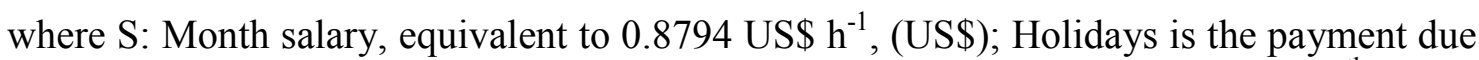
to holidays as a percentage of monthly wage $(\%)$; T13 is the thirteen wage payment $\left(13^{\text {th }}\right.$ wage: end of the year bonus paid by law to all labor force in Brazil) as a percentage of salary (\%); INSS 
is the INSS payment to the INSS (National Social Security Institute) as a wage percentage (\%); IT is the INSS payment regarding the $13^{\text {th }}$ wage as a percentage of monthly wage (\%); $\mathrm{Hr}$ are the hours required to apply an irrigation (h); and ITr is the irrigation time increase (decimal).

Additional Maintenance Cost (AMC). The additional costs due to maintenance can be computed using equation 5:

$A M C=M C K v-M C K n$

where MCKn and MCKv are the maintenance costs from the new and old sprayer kit, respectively (R\$). Which are computed by Eq. 6 and 7.

$M C K v=M C K n \cdot I T r$

and,

$M C K n=\Sigma M M C T a$

where $\mathrm{n}$ is the number of CPIM; MCTa is the annual maintenance cost (US\$).

Zocoler (2003) proposed a lifetime cycle and annual maintenance rates (Table 3), for 2000 working hours per year.

Table 3. Lifetime and Maintenance rates for a center pivot irrigation system main components

\begin{tabular}{ccc}
\hline Irrigation System Components & $\begin{array}{c}\text { Lifetime } \\
\text { (year) }\end{array}$ & Tm (\% Vi) \\
\hline Fixed Sprinklers & $7-10$ & $5.0-8.0$ \\
Centrifugal Pump & $16-25$ & $3.0-5.0$ \\
Pumping Station (structure) & $20-40$ & $0.5-1.5$ \\
Diesel Engine & $10-20$ & $5.0-8.0$ \\
Electrical Engine & $20-25$ & $1.5-2.5$ \\
Steel Buried Pipe & $15-25$ & $0.25-0.50$ \\
Surface Steel Galvanized Pipe & $10-20$ & $1.0-2.0$ \\
\hline
\end{tabular}

Note: $\mathrm{Vi}$ is the initial value; $\mathrm{Tm}$ is the maintenance rate

Yield Loses Cost (YLC). Yield loses costs can be calculated using Eq. 8.

$Y L C=Y I K n-Y I K V$

where YIKn is the yield income obtained with the new sprayers kit (US\$); and YIKv is the yield income obtained with the old sprayers kit (US\$). It is defined as:

$Y I K v=\Sigma\left(P C \cdot y_{d i}\right)$ 
where $\mathrm{n}$ is the number of crops harvested per year; Pc is the crop selling price (US\$ kg${ }^{-1}$ ), for potatoes was $0.35 \mathrm{US} \$ \mathrm{~kg}^{-1}$ and for beans was $0.58 \mathrm{US} \$ \mathrm{~kg}^{-1}$; and $\mathrm{y}_{\mathrm{di}}$ is the actual crop production $\left(\mathrm{kg} \mathrm{ha}^{-1}\right)$; and $\mathrm{y}_{\mathrm{di}}$ is defined by Eq. 10 .

$y_{d i}=\left(y_{d A I A} \cdot A I A\right)+\left(y_{d O I A} \cdot O I A\right)+\left(y_{d V I A} \cdot U I A\right)$

where $\mathrm{y}_{\mathrm{dAIA}}$ : properly irrigated area crop yield $\left(\mathrm{kg} \mathrm{ha}^{-1}\right)$, defined as:

$y_{A A A}=a+b \cdot x_{A A A}-c \cdot x_{A I A}^{2}$

where $\mathrm{a}, \mathrm{b}$ and $\mathrm{c}$ are equation adjustment parameters; $\mathrm{x}_{\mathrm{AIA}}$ is the mean irrigation depth at properly irrigated area ( $\mathrm{mm})$; AIA is the properly irrigated area (ha). Defined by Montero et al. (1997) as the area where, during a hydraulic evaluation, the water depth collected has a relationship with the mean collected depth (MCD) defined as: $0.85 \cdot \mathrm{MCD} \leq \mathrm{AIA} \leq 1.15 \cdot \mathrm{MCD}$. MCD is computed by Eq. 12.

$M D C=\frac{\sum_{i=1}^{2}\left(F_{i} s_{i}\right)}{s_{\bar{i}}}$

where Vi is the volume or depth of water collected in the collector "i" ( $\mathrm{ml} \mathrm{or} \mathrm{mm);} \mathrm{Si} \mathrm{is}$ the distance between the collector "i" up to the point of pivot $(\mathrm{m})$; $\mathrm{Y}_{\mathrm{dOIA}}$ is the maximum possible crop yield on over-irrigated area $\left(\mathrm{kg} \mathrm{ha}^{-1}\right)$; OIA is the over-irrigated area (ha), defined as the area that registered during a hydraulic evaluation, a depth greater than $1.15 \cdot \mathrm{MDC} ; \mathrm{Y}_{\mathrm{dUIA}}$ is the maximum possible crop yield on a under-irrigated area $\left(\mathrm{kg} \mathrm{ha}^{-1}\right)$; and UIA is the under-irrigated area (ha), defined as the area that registered, in a hydraulic evaluation, a depth less than $0.85 \cdot \mathrm{MDC}$.

To estimate potatoes crop yield an empirical equation, Eq. 13 proposed by Coelho et al. (1998) was used.

$Y_{p}=-28.31978+0.1818 \mathrm{hi}-0.00014517 \mathrm{hi}^{2}$

where $\mathrm{Y}_{\mathrm{p}}$ is the potatoes yield $\left(\mathrm{T} \mathrm{ha}^{-1}\right)$; and hi is the total water applied (mm).

To estimate beans crop yield an empirical equation, Eq. 14 proposed by Figueredo et al. (1998) was used:

$Y_{b}=-1557.9+16.032 \mathrm{hi}-0.014 \mathrm{hi}^{2}$

where $\mathrm{Y}_{\mathrm{b}}$ is the beans yield $\left(\mathrm{kg} \mathrm{ha}^{-1}\right)$; and hi is the total water applied (mm).

When both equations $(13 \& 14)$ were considered equal to zero and derived, it was maximize the water depth required to obtain maximum yield. Afterward, substituting total water required on Eq. 13 and 14, crop potential yield was determined each crop. 
Determining the minimum Hermann and Hein's Uniformity Coefficient (UCh) value to recommend a sprayer and pressure regulator kit change. Knowing all additional costs for each component of inequality (1), the best fit equation was determined. Having it, the minimum UCh to change the emitter modules was computed.

\section{RESULTS AND DISCUSSION}

It was necessary to simulate water distribution depth along the pivot line for different operation times. Additionally, it was also computed the Hermann and Hein's Uniformity Coefficient (UCh) (1968) (Fig.1).

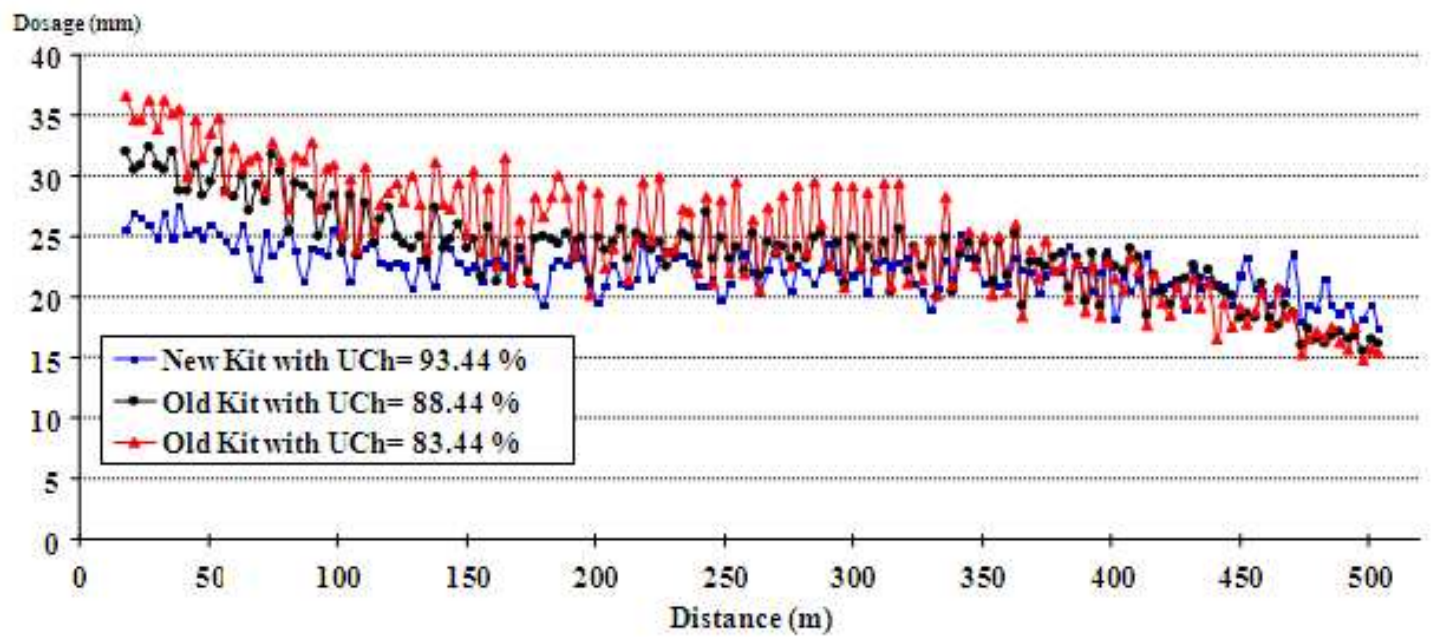

Figure 1. Irrigation depths along the pivot line for different Hermann and Hein's Uniformity Coefficient (UCh) values and operation times.

Additional Consumption Costs (AECC, AWCC, ALC, AMC). Maintenance costs were determined for each system's part. The maximum lifetime value, on Table 3, was used. The equation that relates maintenance rates $(\mathrm{Tm})$ with time of operation $\left(\mathrm{T}_{\mathrm{LC}}\right)$, in years, was also computed. The results were a group of linear equations that are shown on Table 4 for each part of the irrigation system.

Table 4. Best fit equation obtained for each irrigation system part as a function of maintenance rates $(\mathrm{Tm})$ and lifetime $\left(\mathrm{T}_{\mathrm{LC}}\right)$

\begin{tabular}{cc}
\hline Irrigation system component & Equation* \\
\hline Fixed Sprinklers & $\mathrm{Tm}=\mathrm{T}_{\mathrm{LC}}-1$ \\
Centrifugal Pump & $\mathrm{Tm}=0.22 \mathrm{~T}_{\mathrm{LC}}-0.08$ \\
Pumping Station (structure) & $\mathrm{Tm}=0.05 \mathrm{~T}_{\mathrm{LC}}-7 \cdot 10^{-16}$ \\
Diesel Engine & $\mathrm{Tm}=0.3 \mathrm{~T}_{\mathrm{LC}}+2$ \\
Electrical Engine & $\mathrm{Tm}=0.2 \mathrm{~T}_{\mathrm{LC}}-0.1$ \\
Steel Buried Pipe & $\mathrm{Tm}=0.025 \mathrm{~T}_{\mathrm{LC}}-3 \cdot 10^{-16}$ \\
Surface Steel Galvanized Pipe & $\mathrm{Tm}=0.1 \mathrm{~T}_{\mathrm{LC}}-2 \cdot 10^{-15}$ \\
\hline
\end{tabular}


Note: all equations were obtained a $\mathrm{r}^{2}=1$

Afterwards, variable costs for the irrigation system under different uniformity conditions were determined (Table 5). As can be noted costs due to energy consumption represent $72.52 \%$ of total variable costs, follow by water consumption costs $(20.61 \%)$.

Table 5. Energy consumption (ECC), water consumption (WCC), labor consumption (LCC) and maintenance (MC) costs (US\$)

\begin{tabular}{ccccccc}
\hline$\beta / \alpha$ & UCh & ECC & WCC & LCC & MC & Total \\
\hline 1 & 93.44 & 56954.54 & 15973.92 & 1956.72 & 3340.89 & 78226.07 \\
0.995 & 92.44 & 57039.65 & 16054.19 & 1966.55 & 3367.40 & 78427.79 \\
0.977 & 88.44 & 57353.22 & 16349.97 & 2002.79 & 3443.39 & 79149.37 \\
0.954 & 83.44 & 57771.13 & 16744.15 & 2051.07 & 3554.82 & 80121.17 \\
\hline \multicolumn{2}{r}{ Mean $\left(\right.$ US\$ ha $\left.^{-1}\right)$} & 716.00 & 203.51 & 24.93 & 42.83 & 987.26 \\
\hline \multicolumn{2}{c}{ Total $(\%)$} & 72.52 & 20.61 & 2.53 & 4.34 & 100 \\
\hline
\end{tabular}

Eq. 13 and Eq. 14 were used to determine each crop yield under different irrigation uniformity conditions. With that information, net incomes were determined (Table 6).

Table 6. Net income for potato and bean crops obtained for different uniformity conditions

\begin{tabular}{cccccc}
\hline$\beta / \alpha$ & $\begin{array}{c}\text { UCh } \\
(\%)\end{array}$ & $\begin{array}{c}\text { Potato } \\
(\text { US\$) }\end{array}$ & $\begin{array}{c}\text { Bean } \\
\text { (US\$) }\end{array}$ & $\begin{array}{c}\text { Total } \\
(\text { US\$) }\end{array}$ & $\begin{array}{c}\text { Total Yield } \\
\text { Losses } \\
(\text { US\$) }\end{array}$ \\
\hline 1 & 93.44 & 247295.45 & 37168.82 & 284464.27 & - \\
0.995 & 92.44 & 246197.41 & 37159.28 & 283356.69 & 1107.58 \\
0.977 & 88.44 & 235623.33 & 36997.50 & 272620.83 & 11843.44 \\
0.954 & 83.44 & 228520.24 & 36611.92 & 265132.16 & 19332.11 \\
\hline \multicolumn{2}{l}{ Mean $\left(\mathrm{US} \mathrm{ha}^{-1}\right)$} & 2992.61 & 462.30 & 3454.92 & - \\
\hline
\end{tabular}

Using values from tables $4 \& 5$ into Eq. 1, Table 7 was developed to compare the cost of using irrigation water emitter sets with different UCh.

Table 7. Additional consumptions cost for different irrigation uniformity values (US\$)

\begin{tabular}{ccccccc}
\hline $\begin{array}{c}\text { UCh } \\
(\%)\end{array}$ & $\begin{array}{c}\text { AECC } \\
\text { (US\$) }\end{array}$ & $\begin{array}{c}\text { AWCC } \\
\text { (US\$) }\end{array}$ & $\begin{array}{c}\text { ALC } \\
\text { (US\$) }\end{array}$ & $\begin{array}{c}\text { AMC } \\
\text { (US\$) }\end{array}$ & $\begin{array}{c}\text { YLC } \\
\text { (US\$) }\end{array}$ & $\begin{array}{c}\text { Total Cost } \\
\text { (US\$) }\end{array}$ \\
\hline 93.44 & \multicolumn{5}{c}{ Reference values } \\
92.44 & 85.11 & 80.27 & 9.83 & 26.51 & 1107.58 & 1309.30 \\
88.44 & 398.68 & 376.05 & 46.07 & 102.50 & 11843.44 & 12766.74 \\
83.44 & 816.59 & 770.23 & 94.35 & 213.93 & 19332.11 & 21227.21 \\
\hline
\end{tabular}

From total costs, the best fit equation was determined taking under consideration UCh values. From this analysis, and knowing the cost to change the sprayer and pressure regulator kits (US\$ 7 799.40), equation 15 was obtained. 
$Y=-130.25 \cdot U C h^{2}+20696 \cdot U C h-798769$

where $\mathrm{Y}$ is the sprayer and pressure regulator kits cost (\$); and UCh is the Hermann and Hein's uniformity coefficient (\%).

If variable Y in Eq. 15 is substituted by US\$ 7799.40, then the UCh limit value that makes economically feasible to substitute the sprayer and pressure regulator kit, can be determined. In this exercise, the value is $90.37 \%$. Meaning that for values inferior to this UCh, economic loses will be higher that the installation cost of a new sprinkling module in the CPIM.

\section{CONCLUSIONS}

The theoretical model application allows predicting the effect of spray and pressure regulator kit worn out on irrigation uniformity and labor costs for any crop and under certain climatic condition.

Therefore, the objective of knowing the threshold to produce economic profit as a function of irrigation uniformity and depth of irrigation water applied was established.

The variables with higher influences are water cost (20.61\%) and energy costs $(72.52 \%)$. A reduction of $3.07 \%$ from the maximum UCh obtained with a new set of sprayer and pressure regulator kit ( $\mathrm{UCh}=93.44 \%)$ indicates that when $\mathrm{UCh}=90.37 \%$ is obtained, after a CPIM evaluation, the change of all appurtenances would be economically feasible.

\section{RECOMMENDATIONS}

$i$. To develop computer software that performs all computations presented in this paper.

ii. The application of this methodology to a real study case.

iii. Considering that a small variation of UCh justified the substitution of the entire sprinkling module, it is recommended to perform several pluviometric evaluations to confirm the best UCh value and avoid the possible effect on Hermann and Hein's uniformity coefficient from other climate and operational factors.

\section{REFERENCES}

COELHO, R. D.; FOLEGATTI, M. V.; FRIZZONE, J. A. Simulação da produtividade de batata em função da regulagem do aspersor (sistema portátil). Revista Brasileira de Engenharia Agrícola e Ambiental, v. 2, n. 3, p. 273-277, 1998.

COMPANHIA PAULISTA de FORÇA e LUZ. Tarifas para o fornecimento de energia elétrica. Resolução No 553/ANEEL DOU de 23/10/2007. Disponível em:

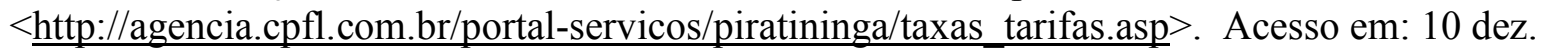
2007 
FIGUERÊDO, S. F., et. al. Estabelecimento do momento de irrigação com base na tensão da água no solo para cultura do feijoeiro. Revista de Engenharia Rural, v. 9, n. 2, p. 1-95, 1998.

HERMANN, D. F.; HEIN, P. R. Performance characteristics of self-propelled center-pivot sprinkler irrigation system. Transations of the ASAE, v. 11, n. 1, p. 11-15, 1968.

MONTERO, J., et. al. Análisis de la distribución de agua en riegos con equipos pívot. In:

CONGRESO NACIONAL DE RIEGOS, 15., 1997, Lérida. P. 481-490.

PÉREZ, R.; SÁNCHEZ-ROMÁN, R. M.; FRIZZONE, J. A. Optimal moment to change pressure regulators and sprayers kit on center pivot irrigation machines: A theoretical model proposal. IRRIGA, Botucatu, 2011.

PERI, G.; HART, W. E.; NORUM, D. I. Optimal irrigation depths-a method of analysis. IRRIGA, Botucatu, V. 105, n. 4, p. 341-355, 1979.

WOOD, M.; WANG, Q. J.; Bethune, M. An economic analysis of conversion from border-check to centre pivot irrigation on dairy farms in the Murray Dairy Region, Australia. Irrigation Science, v. 26, p.9-20, 2007

ZOCOLER, J. L. Análise econômica de sistemas de irrigação. In: Miranda JH, Pires RCM (ed) Irrigação, Jaboticabal, 2003. p. 653-703. 